\title{
STRATEGI MENUMBUHKAN JIWA KREATIF DAN INOVATIF DALAM KEWIRAUSAHAAN
}

Taufik Hidayat, Zuhrinal M. Nawawi

Universitas Islam Negeri (UIN) Sumatera Utara, Medan, Indonesia

Email: taufikhidayatinst@gmail.com, zuhrinal.nawawi@uinsu.ac.id

\begin{tabular}{ll}
\hline INFO ARTIKEL & ABSTRAK \\
\hline Diterima & Kewirausahaan merupakan suatu kegiatan untuk meningkatkan \\
11 November 2021 & kesejahteraan masyarakat dalam arti tingkatan hidup yang lebih baik lagi. \\
Direvisi & Kewirausahaan merupakan salah satu program studi manajemen \\
23 November 2021 & kewirausahaan di Fakultas Ekonomi dan Bisnis Islam di Universitas \\
Disetujui & Negeri Sumatera Utara. Kewirausahaan sangat berperan penting dalam \\
3 Januari 2022 & perkembangan pertumbuhan ekonomi. Kewirausahaan diharapkan dapat \\
Kata Kunci: & mengurangi tingkat pengangguran di Indonesia dengan berlandaskan \\
Strategi; Kreatif; & sikap kreatif dan inovatif mampu bertahan dan berkembang dalam \\
Inovatif; & kondisi ekonomi yang sulit. Berdasarkan latar berlakang tersebut maka \\
Kewirausahaan & tujuan dari penelitian ini adalah untuk menganalisis strategi untuk \\
& menumbuhkan jiwa kreatif dan inovatis dalam kewirausahaan. Teknik \\
& yang digunakan adalah teknik analisis data dengan dokumentasi. \\
& Berdasarkan penelitian dapat disimpulkan bahwa, selain menumbuhkan \\
& jiwa kreatif dan inovatif bagi wirausaha serta memiliki kompetensi \\
& kewirausahaan tetapi wirausahawan juga perlu memiliki jiwa seperti \\
& skill, conceptual skill, human skill, decision making dan time managerial \\
& skill.
\end{tabular}

\begin{abstract}
Entrepreneurship is an activity to improve people's welfare in the sense of a better standard of living. Entrepreneurship is one of the entrepreneurial management study programs at the Faculty of Islamic Economics and Business at the State University of North Sumatra. Entrepreneurship plays an important role in the development of economic growth. Entrepreneurship is expected to reduce the unemployment rate in Indonesia based on a creative and innovative attitude that is able to survive and thrive in difficult economic conditions. Based on this background, the purpose of this study is to analyze strategies to foster a creative and innovative spirit in entrepreneurship. The technique used is data analysis technique with documentation. Based on the research, it can be concluded that, in addition to fostering a
\end{abstract} Keywords: creative and innovative spirit for entrepreneurs and having Strategy; Creative; entrepreneurial competencies, entrepreneurs also need to have souls Innovative; $\quad$ such as skills, conceptual skills, human skills, decision making and time Entrepreneurship managerial skills.

\section{Pendahuluan}

Berwirausaha adalah salah satu jalan yang dapat digunakan untuk meningkat taraf hidup selain menjadi seorang pedagang maupun buruh karena dengan berwirausaha

$\begin{array}{ll}\text { How to cite: } & \text { Hidayat, Taufik, Zuhrinal M. Nawawi (2022). Strategi Menumbuhkan Jiwa Kreatif Dan Inovatif Dalam } \\ & \text { Kewirausahaan, Action Research Literate, 6(1). } \\ \text { E-ISSN: } & 2721-2769 \\ \text { Published by: } & \text { Ridwan Institute }\end{array}$


menjadi suatau peluang untuk memperoleh penghasilan (Koranti, 2013).

Wirausahawan adalah orang yang dapat melihat adanya peluang kemudian menciptakan sebuah organisasi untuk memanfaatkan peluang seperti memiliki kegiatan fungsi dan tindakan untuk mengerjakan dan memanfaatkan peluang dengan menciptakan suatu organisasi (Kurniullah et al., 2021).

Harapan untuk diterima kerja didunia kerja tentunya tidaklah keliru, namun tidak dapat dipungkiri bahwa kesempatan kerja pun sangat terbatas dan tidak berbanding lurus dengan lulusan lembaga baik itu dasar, menengah maupun tinggi (Megawati \& Farida, 2018). Oleh sebab itu semua pihak harus terus berpikir dan mewujudkan karya nyata dalam mengatasi kesenjangan antara laporan pekerjaan dengan lulusan institusi pendidikan.

Kesenjangan ini menyebabkan peningkatan angka pengangguran. Pengangguran adalah masalah utama dalam pembangunan yang sangat kritis, khususnya di pelosok nusantara. Salah satu solusinya adalah mencetak lulusan lembaga pendidikan yang memilikipotensi dalam pengembangan keterampilan menjadi usaha mandiri. Selain untuk menjadi solusi untuk diri sendiri, tapi juga menjadi solusi untuk orang lain yang tidak memiliki pekerjaan. Ada beberapa alasan orang untuk berwirausaha, antara lainuntuk mencari nafkah, maupun menambah pendapatan, untuk memperoleh status maupun ingin dikenal maupun bertemu orang banyak, memberikan pelayanan pada masyarakat, dan untuk mandiri dan lebih produktif (Malawat, 2019). Semua alasan tersebut itulah yang mendorong orang untuk berwirausaha. Dan dapat di artikan bahwa wirausaha merupakan suatu prosesatau suatu usaha yang dilakukan dengan tujuan mendapatkan keuntungan sesuai dengan harapan dengan cara dengan memproduksi, maupun menjual barang atau jasa.
Dalam dunia bisnis yang semakin berkembang dengan pesatnya maka semakin banyak pula perusahaan yang berdiri sehingga terjadinya banyak persaingan yang semakin tajam di perusahaan yang sejenis (Martinus, 2011). Seiring dengan berkembangnya zaman yang semakin pesat maka seorang wirausaha harus lebih kreatif dan inovatif dalam membuat karya usaha suatu produk sehingga dapat menerapkan prinsip ekonimi bisnis islam. Menghadapi permasalahan dan tantangan dalam sebuah usaha tentunya seseorang harus memiliki karakter dan sikap kewirausahaannya dalam menjalakankan dan menciptakan produik dalam usahanya.

Dalam menjalankan suatu usaha, wirausahawan harus memiliki skill (Kemampuan) sebagai modal utama wirausawan dalam menjalankan usahanya, Tekad (kemauan) juga harus dimiliki oleh wirausahawan, jika tidak ada tekad maka usaha yang kita lakukan tidak akan berjalan dengan baik (Soegoto, 2013). Selain itu, modal juga menjadi salah satu kewajiban yang harus dimiliki bagi seorang wirausahawan sebagai aspek penunjang usaha dalam memulai suatu uasaha, Target dan tujuan juga sangat diperlukan bagi seorang wirausaha karena dalam memulai dan menjalankan suatu usaha harus memiliki target dan tujuan pemasaran yang ingin di tempuh demi bertahannya suatu usaha. Tempat berwirausaha merupakan aspek yang harus dimiliki dan menunjang dalam berwirausaha dan menjadikan suatu bahan pertimbangan oleh konsumen mengenai usaha yang dijalankan.

\section{Metode Penelitian}

Penelitian ini menggunakan jenis penelitian deskriptif yaitu penelitian yang dilakukan untuk mengetahui gambaran dari suatu usaha yang akan dilakukan dan mampu menumbuhkan suatu sikap kreatif dan inovatif dalam kewirausahaan yang diteliti (Sugiyono, 2017). 
Variabel dalam penelitian ini adalah cara menumbuhkan sikap kreatif dan inovatif dalam diri seorang wirausahawan. Data dalam penelitian ini diperoleh melalui kegiatan dokumentasi dengan menggunakan teknik analisis data.

\section{Hasil dan Pembahasan}

Kewirausahaan berasal dari kata "wira" dan "usaha". Wira yang berarti pejuang, pahlawan, manusia unggul, teladan, berbudi luhur, gagah dan berwatak agung. Usaha itu sendiri adalah perbuatan, pekerja, bekerja dan berbuat sesuatu. Jadi wirausaha adalah pejuang yang melakukan sesuatu hal.

Menurut KBBI wirausaha adalah orang yang pandai atau berbakat mengenali produk baru, mengatur permodalan operasinya, setta memasarkannya. Dalam lampiran keputusan Menteri Koperasi dan Pembinaan Perusahaan Kecil Nomor 961/KEP/M/XI/1995, dicantumkan bahwa :

1. Wirausaha adalah orang yang mempunyai semangat, sikap, perilaku dan kemampuan usaha.

2. Kewirausahaan adalah semangat, sikap, perilaku dan kemampuan seseorang dalam menangani usaha atau kegiatan yang mengarah pada upaya mencari, menciptakan serta menerapkan cara kerja, teknologi produk baru dengan meningkatkan efisiensi dalam rangka memberikan pelayanan yang lebih baik atau memperoleh keuntungan yang lebih besar.

Jadi wirausaha itu mengarah kepada orang yang melakukan kegiatan atau usaha sendiri dengan kemampuan yang dimilikinya. Sedangkan kewirausahaan mengarah kepada sikap dan perilaku orang/wirausaha dalam melaksanakan usaha/kegiatan (Intansih et al., 2021). Kewirausahaan dilihat dari sumber daya berupa tenaga kerja, material dan aspek lainnya dalam suatu kombinasi yang dapat menambah nilai atau bisa juga dikatakan sebagai orang yang dapat membawa perubahan maupun membuat atau mengubah sesuatu dengan kreatif dan inovatif serta aturan-aturan baru. Kewirausahaan dalam arti proses yang dinamis diaman kewirausahaan merupakan sebuah proses mengkreasi dengan menambahkan nilai sesuatu yang dicapai melalui usaha keras dan waktu yang tepat dengan memperkirakan dana pendukung, fisik, resiko sosial dan akan menerima reward berupa keuangan dan kepuasan serta kemandirian personal.

Menurut (Hasibuan et al., 2021) Kewirausahaan merupakan suatu kemampuan dalam menciptakan nilai tambah dipasar melalui proses pengelolaan sumber daya dengan cara-cara baru dan berdeba melalui :

a. Pengembangan teknologi baru

b. Penemuan pengetahuan ilmiah baru

c. Perbaikan produk barang dan jasa yang ada

d. Penemuan cara-cara baru untuk menghasilkan barang lebih banyak dengan sumber daya lebih efisien.

Kreativitas adalah kemampuan untuk mengembangkan ide-ide baru dan cara-cara baru dalam pemecahan masalah dan menemukan peluang. Proses kreativitas diantaranya adalah : Adanya keinginan untuk menciptakan sesuatu yang lain berdasarkan situasi dan kondisi yang ada, berfikir untuk menciptakan/ mewujudkan hasil pemikiran tersebut, Melakukan Uji coba dan hasil pemikiran tersebut, Menyempurnakan hasil uji coba, Mewujudkan hasil kreativitas, Memperbanyak hasil kreativitas.

Adapun pengembangan kreativitas menurut Jordan E. Ayan dalam bukunya Bengkel Kreativitas, mengungkapkan cara pengembangan kreativ, yaitu dengan C.O.R.E

a. Cari tahu, Kita selalu bertanya ketika mendapatkan permasalahan dan berpikir untuk mencari jalan keluarnya. 
b. Oleh keterbukaan. Bersikaplah terbuka pada hal-hal baru, meski terasa aneh dan janggal.

c. Kamu harus berani melawan arus, melakukan untung-untungan bahkan menjadi bahan tertawaan.

d. Teruslah bersemangat dalam melakukan sesuatu, kreativitas kamu akan muncul dengan sendirinya.

Inovasi adalah kemampuan untuk menerapkan kreativitas dalam rangka pemecahan masalah dan menemukan peluang. Prinsip-prinsip inovasi ada dua, yaitu Prinsip keharusan dan Prinsip Larangan.

Prinsip keharusan diantaranya adalah keharusan menganalisis peluang, keharusan memperluas wawasan, keharusan untuk bertindak efektif, keharusan untuk tidak berpikir muluk.

Prinsip Larangan adalah Larangan untuk berlagak pintar, larangan untuk rakus, Larangan untuk berpikir terlalu jauh kedepan.

Proses inovasi adalah adanya masalah atau tantangan dalam kehidupan yang dihadapi oleh manusia, berpikir menciptakan sesuatu yang baru untuk mengatasi masalah atau tantangan yang ada, melakukan uji coba dan hasil pemikiran tersebut, menyempurnakan hasil uji coba, mewujudkan hasil inovasi, memperbanyak hasil inovasi.

Untuk mengembangkan cara berpikir inovatif, dapat dilakukan dengan cara-cara sebagai berikut: Membiasakan memiliki mimpi, Memperkaya sumber ide, Membiasakan diri menerima perbedaan dan perubahan, Menumbuhkan sikap empati, kemampuan inovatif, Menerapkan Kemampuan Inovatif.

Seorang wirausaha yang inovatif dikenal mempunyai kemampuan menggabungkan imajinasi dan pikiran kreatif secara sistematis dan logis. Kombinasi tesebut menjadi bekal penting bagi keberhasilan didalam berwirausaha.

Menurut Kuratko (1995) ada 4 jenis proses penerapan kemampuan inovatif yaitu :
Penemuan (invensi) adalah produk, jasa atau proses yang benar-benar baru, Pengembangan (ekstensi) adalah pemanfaatan baru atau penerapan lain pada produk, jasa atau proses yang ada, Penggandaan (duplikasi) adalah replikasi kreatif atas konsep yang telah ada, Sintesis adalah kombinasi atas konsep dan faktor-faktor yang telah ada dalam penggunaan atau formulasi baru.

Jadi kreativitas adalah kemampuan untuk memikirkan sesuatu yang baru dan berbeda, sedangkan inovasi merupakan kemampuan untuk melakukan sesuatu yang baru dan berbeda. Melalui pengertian tersebut terdapat empat hal yang dimiliki oleh seseorang wirausahawan yakni :

Proses berkereasi merupakan mengkreasikan sesuatu yang baru dengan menambah nilainya. Pertambahan nilai ini tidak hanya diakui oleh wirausahaan semata tapi juga orang lain yang menggunakan kreasi tersebut.

Komitmen yang tinggi terhadap penggunaan waktu dan usaha yang diberikan. Semakin besar focus dan perhatian yang diberikan dalam usaha ini maka akan mendukung proses kreasi yang akan timbul dalam kewirausahaan.

Memperkirakan resiko yang mungkin timbul. Dalam hal resiko yang munngkin terjadi berkisar pada resiko keuangan, fisik dan resiko sosial.

Memperkirakan reword dalam hal ini reword yang terpenting adalah kebebasan yang diikuti dengan kepuasan pribadi. Sedangkan reward yaitu berupa uang yang biasanya dianggap sebagai suatu bentuk derajat kesuksesan usahanya.

1. Jiwa dan Sikap Kewirausahaan

a. Percaya diri (Self confidence) Merupakan paduan sikap dan keyakinan seseorang dalam menghadapi tugas atau pekerjaan yang bersifat internal, sangat relative, dam dinamis yang ditentukan dari kemampuan untuk memulai, 
melaksanakan dan menyelesaikan suatu pekerjaan. Kepercayaan mempengaruhi gagasan, inisiatif, kreativitas, keberanian, ketekunan, semangat kerja, dll.

b. Disiplin, dalam berwirausaha, seorang wirausahawan harus memiliki sikpa disiplin yang tinggi. Maksud dari disiplin disini adalah ketepatan komitennya terhadap usahanya tersebut. Ketepatan yang dimaksud disini adalah ketepatan waktu, kualitas pekerjaan, system kerja, dsb. Ketepatan terhadap waktu dapat dibina dengan cara berusaha mengerjakan pekerjaan sesuai dengan waktu yang direncanakan. Sifat sering menunda pekerjaan adalah sikap yang dapat menghambat seseorang wirausahawan meraih keberhasilan.

c. Komitmen tinggi, komitmen merupakan suatu kesepakatan mengenai sesuatu hal yang dibuat oleh dirinya maupun orang lain. Dalam menjalankan suatu usaha, wirausahwan harus memiliki komitmen yang jelas, terarah dan berorientasi pada kemajuan. Komitmen terhadap diri sendiri dapat dibuat dengan identifikasi cita-cita, harapan, dan target-target yang direncanakan dihidupnya. Sedangkan komitmen dengan orang lain terutama untuk konsumen diantaranya adalah pelayanan prima yang berorientasi kepada kepuasan konsumen, kualitas produk yang sesuai dengan harga produk yang ditawarkan, dll.

d. Kujujuran, kejujuran merupakan landasan moral yang kadang-kadang dilupakan oleh wirausahawan. Kejujuran dalam berperilaku bersifat kompleks. Kejuuran mengenai karakteristik produk dan jasa yang ditawarkan, kejujuran mengenai promosi yang dilakukan, kejujuran mengenai pelayanan yang dijanjikan dan kejujuran mengenai segala kegiatan yang terkait dengan penjualan produk yang dilakukan.

e. Berorientasi dengan tugas dan hasil seseorang yang mengutamakan tugas dan hasil adalah orang-orang yang selalu mengutamakan nilai-nilai motif berprestasi, berorientasi pada laba, ketekunan dan kerja keras. Peluang hanya bisa didapat dengan inisiatif. Inisiatif dapat ditumbuhkan dengan cara penelitian dan pengalaman bertahun-tahun depengembangannya diperoleh dengan cara disiplin diri, berpikir kritis, tanggap, dan berprestasi.

f. Keberanian mengambil resiko, wirausaha adalah orang-orang yang menyukai usaha-usaha yang lebih menantang untuk mencapai kesuksesan atan kegagalan daripada usaha yang kurang menantang. Pilihan terhadap resiko bergantung pada :

1) Kesediaan untuk rugi

2) Kemungkinan relative untuk sukses atau gagal.

Selanjutnya kemampuan mengambil resiko tergantung dari:

1) Keyakinan pada diri sendiri

2) Kesediaan untuk menggunakan kemampuan dalam mencari peluang dan kemungkinan untuk memperoleh keuntungan.

3) Kemampuan untuk menilai resiko secara realis.

g. Kepemimpinan Memiliki jiwa kepemimpinan (berani tampil berbeda dan berani mengambil resiko dengan penuh perhitungan) Leadership atau kepemimpinan merupakan faktor utama menjadi wirausahawan sukses. Berani tampil ke depan menghadapi sesuatu yang baru walaupun penuh resiko. Keberanian ini tentunya dilandasi perhitungan yang rasional. Seorang yang takut untuk tampil 
memimpin dan selalu melemparkan tanggung jawab kepada orang lain, akan sulit meraih sukses dalam berwirausaha. Sifat-sifat tidak percaya diri, minder, malu yang berlebihan, takut salah dan merasa rendah diri adalah sifat-sifat yang harus ditinggalkan dan dibuang jauh-jauh dari diri kita apabila ingin meraih sukses dalam berwirausaha. Serta mempuyai ide-ide kreatif dan inovatif yang dapat menjadi pelopor dalam memproduksi barang maupun pemasaran.

h. Keorsinilan, kreativitas dan inovatif, wirausaha yang inovatif adalah wirausaha yang memiliki ciri-ciri :

1) Tidak pernah puas dengan apapun yang dilakukan, walaupun itu sudah cukup baik.

2) Selalu menuangkan imajinasi dalam segala sesuatu yang dikerjakannya.

3) Selalu ingin tampil beda dan memanfaatkan perbedaan itu.

Menurut Everett E. Hagen dalam (Sukirman, 2017) ciri-ciri innovational personality sebagai berikut :

1) Openness to experience, terbuka terhadap pengalaman.

2) Creativ imagination, kemampuan bekerja dengan penuh imajinasi

3) Confidence and content in one's own evaluation, memiliki keyainan atas penilaian dirinya dan teguh pendirian.

4) Satisfiction in facing and attacking problems and in resolving confusion or inconsistency, selalu memiliki kepuasan dalam menghadapi dan memecahkan persoalan.

5) Has a duty or responsibility to achieve, memiliki tugas dan rasa tanggung jawab untuk berprestasi.

6) Inteigence and energetic, memiliki kecerdasan dan energik.
Menumbuhkan Jiwa dan Kompetisi Kewirausahaan :

1) Menumbuhkan jiwa Wirausaha Mungkin kita beranggapan bahwa orang yang keluarganya kaya akan melahirkan anak yang hidup kaya karena mereka terbiasa kaya. Sama juga halnya dengan yang mempunyai ayah dan ibu seorang pengusaha tentunya banyak yang berpikir bahwa mereka juga dulunya adalah keturunan pengusaha. Tidak bisa dipungkiri bahwa banyak pengusaha yang juga terlahir dari keturunan pengusaha. Tetapi belum tetntu diturunkan secara genetis. Mungkin hal ini terjadi karena pengaruh lingkungan yang cukup kuat yang membuat seseorang menjadi seorang pengusaha. Menjadi pengusaha merupakan kebebasan individu. Jangan karena tidak mempunyai keturunan pengusaha, orang tidak bisa menjadi wirausaha. Langkah awal menjadi wirausaha adalah dengan menumbuhkan jiwa kewirausahaan di diri kita. Banyak cara yang dapat dilakukan misalnya :

a) Melalui pendidikan formal. Kini sekolah atau perguruan tinggi telah banyak yang menyajikan program atau mata kuliah kewirausahaan.

b) Melalui seminar-seminar kewirausahaan, yaitu berbagai seminar yang diselenggarakan dengan mengundang pakar dan praktisi kewirausahaan.

c) Kewirausahaan di diri kita.

d) Melalui pelatihan.

e) Otodidak.

2) Menumbuhkan

Kompetensi

Kewirausahaan, wirausaha yang sukses pada umumnya yang memiliki kompetensi yaitu seseorang yang memiliki ilmu pengetahuan, keterampilan dan kualitas individu yang meliputi sikap, motivasi, nilai 
serta tingkah laku untuk melaksanakan pekerjaan/kegiatan. Keterampilan yang harus dimiliki oleh seorang wirausaha adalah :

a) Managerial skill Atau yang biasa disebut keterampilan manajerial merupakan bekal yang harus dimiliki wirausaha. Seorang wirausaha harus bisa menjalankan fungsi-fungsi perencanaan, pengorganisasian, pergerakan dan pengawasan agar usaha yang dijalankan dapat mencapai tujuan. Secara garis besar ada dua cara untuk menumbuhkan kemampuan manajerial, yaitu melalui jalur formal dan informal.

b) Conceptual skill Kemampuan untuk merumuskan tujuan, kebijakan dan strategi usaha merupakan landasan utama menuju wirausaha sukses.

c) Human skill (keterampilan memahami, mengerti, berkomunikasi dan berelasi) Supel, mudah bergaul, simpati dan empati kepada orang lain adalah modal keterampilan yang sangat mendukung kita menuju keberhasilan usaha.

d) Decision making skill (keterampilan merumuskan masalah dan mengambil keputusan) Wirausaha dituntut untuk mampu menganalisis situasi dan merumuskan berbagai masalah untuk dicarikan berbagai alternative pemecahannya.

e) Time managerial skill (keterampilan mengatur dan menggunakan waktu) Pakar-pakar psikologi mengatakan bahwa salah satu penyebab atau sumber stress adalah ketidakmampuan seseorang dalam mengatur waktu dan pekerjaan. Seorang wirausaha harus terus belajar mengelola waktu. Keterampilan mengelola waktu dapat memperlancar pelaksanaan pekerjaan dan rencana-rencana yang telah digariskan

\section{Kesimpulan}

Jadi kesimpulan yang dapat diambil adalah dalam meniti dunia usaha terlebih dahulu harus ditumbuhkan dan dikembangkan kompetensi kewirausahaan. Ada banyak cara yang dapat dilakukan diantaranya adalah melalui pendidikan secara formal, melalui seminar-seminar kewirausahaan, melalui pendidikan dan secara otodidak. Orangorang yang memiliki jiwa kewirausahaan yakni mereka yang percaya diri, inisiatif, motif berprestasi, jiwa kepemimpinan, dan suka tantangan. Selain menumbuh kembangkan dan memiliki jiwa serta kompetensi kewirausahaan, mereka wirausahawan juga perlu memiliki keterampilan khusus yakni managerial skill, conceptual skill, human skill, decision making skill, dan time managerial skill.

\section{BIBLIOGRAFI}

Hasibuan, A., Novita, D., Tarigan, N. M. R., Yusrita, Y., \& Riana, Z. (2021). Kewirausahaan. Yayasan Kita Menulis.Google Scholar

Intansih, I., Nuraini, K., \& Putri, S. F. (2021). Tantangan Wirausahawan Muda dalam Beradaptasi di Era Society 5.0 (Studi Kasus pada Mahasiswa Pendidikan IPS). Prosiding National Seminar on Accounting, Finance, and Economics (NSAFE), 1(3). Google Scholar

Koranti, K. (2013). Analisis Pengaruh Faktoreksternal Dan Internal Terhadap Minat Berwirausaha. Prosiding PESAT, 5. Google Scholar

Kurniullah, A. Z., Simarmata, H. M. P., Sari, 
A. P., Sisca, S., Mardia, M., Lie, D., Anggusti, M., Purba, B., Mastuti, R., \& Dewi, I. K. (2021). Kewirausahaan dan Bisnis. Yayasan Kita Menulis. Google Scholar

Malawat, M. S. (2019). Kewirausahaan Pendidikan. Deepublish. Google Scholar

Martinus, H. (2011). Analisis industri retail nasional. Humaniora, 2(2), 1309-1321. Google Scholar

Megawati, M., \& Farida, L. E. (2018). Strategi Menumbuhkan Jiwa Kewirausahaan yang Kreatif dan Inovatif. Proceeding of National Conference on Asbis, 3, 296-302.
Google Scholarv

Soegoto, E. S. (2013). Entrepreneurship menjadi pebisnis ulung. Elex Media Komputindo. Google Scholar

Sugiyono. (2017). Metode Penelitian Kuantitatif, Kualitatif, dan $R \& D$. Alfabeta. Google Scholar

Sukirman, S. (2017). Jiwa Kewirausahaan dan Nilai Kewirausahaan Meningkatkan Kemandirian Usaha melalui Perilaku Kewirausahaan. Jurnal Ekonomi Dan Bisnis, 20(1), 113-131. Google Scholar

\section{Copyright holder :}

Taufik Hidayat, Zuhrinal M. Nawawi (2022).

First publication right :

Action Research Literate

This article is licensed under:

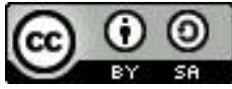

